\title{
A LOOK AT TAIWAN'S COOPERATION WITH PARAGUAY (2009 - 2019)
}

\section{Maria Antonella Cabral López ${ }^{1}$}

\section{Introduction}

The Republic of China - Taiwan is a complex territory because of its historical development. This island of $35,980 \mathrm{~km}^{2}$ (Central Intelligence Agency 20I9), is located I6o kilometres away from China, and was first occupied by settlers of Malay-Polynesian origin and then by Japanese or Chinese settlers, on which there are different assessments. Although there are previous explorations towards the sixth century, it was towards the fifteenth century, during the Ming Dynasty, when the closest contacts with China began. It was subsequently established as the Dutch colony of "Ilha Formosa", but this only lasted a couple of decades until it was established as a district of the Chinese province of Fujian (Toro Dávila, Chacón Morales and Pérez Le-Fort 200I).

In 1885 it was established as a province of China, which under the Treaty of Shimonoseki, had to cede this island to Japan, that had won the first Sino-Japanese war in I895 (Ríos 20I6). After the end of World War II and the Civil War (I946-I949), the People's Republic of China was established ${ }^{2}$. This prompted the Kuomintang ${ }^{3}$ to reach Taiwan and establish, under the leadership of Chang KaiShek, an authoritarian government with the United States's support (Arnone 20I7). US recognition of Taiwan's sovereignty, ceased in I979- even though it remains the same, but under other circumstances (Library of Congress of the United States of America 2005).

\footnotetext{
I Professor of International Economics at the National University of Asunción, Paraguay. E-mail: antocabral@gmail.com

2 Due to the similarity in the official denominations, and in order to simplify the reading, this article has chosen to name the Republic of China- Taiwan or Insular China as Taiwan (or Taipei), and the People's Republic of China or Continental China as China.

3 “Chinese Nationalist Party" (Arnone 20I7).
} 
This last fact influenced so that the countries of the West progressively followed the same path. According to Ríos (20I9), only I7 countries recognized Taiwan in February 2019, all of them islands of the Pacific, the Caribbean Sea and Latin America, an exception to the Vatican and Swaziland. The number fell to I5 in September of the same year, when in the same week, Solomon Islands and Kiribati stopped recognizing Taiwan ${ }^{4}$. In South America, Paraguay is the only country that maintains relations with Taipei, which makes it a relevant ally for this island.

Diplomatic relations between Paraguay and Taiwan date from I957 (Embassy of the Republic of Paraguay in the Republic of China (Taiwan), 2018; Ministry of Finance, 2019). At that time, the Paraguayan Ambassador in Venezuela, Carlos Montanaro, and Taiwanese Foreign Minister Yeh, Kung Chao signed an "Agreement for Diplomatic Notes for the Establishment of Diplomatic Relations" in Caracas (Fleitas 20I7).

The bilateral relationship has extended over time and with relative intensity. The purpose of this material is to present the fundamental aspects of Taiwan's cooperation with Paraguay in the last decade. The article is divided into four sections: the first one introduces the issue of South-South Cooperation (SSC); while in the second it considers Taiwan as an actor of international cooperation. The third addresses the bilateral relationship between the Asian country and Paraguay; summing up, it is presented a synthesis on the cooperation carried out between 2009-2019.

\section{Methodology}

This research is a bibliographic-documentary type. For its development diverse sources were used such as scientific journals, books, periodicals, treaties, reports and other documents. The level of this research was descriptive, since its purpose was to present the fundamental aspects of Taiwan's SCC with Paraguay for the 2009-20I9 period. This issue is relevant in attention to the dispersion of the available information and the shortage of documentation about this issue. The main aspects and the synthesis for the article were obtained through and analytical method, which allowed us to reach and present these results.

4 The Solomon Islands announced its decision in I6/09/2019 and Kiribati in 20/09/2019 


\section{Results}

\section{South-South cooperation: some previous concepts}

Cooperation implies a link between international actors, which seeks the mutual satisfaction of interests by making use of the resources available for them for the implementation of coordinated and/or solidarity actions (Calduch cited by Ayllón 2007). Sotillo (20II) explains the development of cooperation as a part of international cooperation and this last theme does not have a unique, adjusted and complete definition, valid for all times and places.

The latter author argues that cooperation has been loading and downloading content. Because of this, it is essential to be clear about the priorities for development, since these are the ones that will serve to establish the content and objectives that condition the types of development cooperation (Sotillo, 20II). In this same sense, Calabuig Tormo et al. (20I0) present a review of the different predominant conceptions of development and the influence which they have exerted on cooperation activities over the last decades.

Likewise, Fernández Franco and Román Marugán (2013) cite four characteristics of the international cooperation system: a. Discretionality, because the basis is the free will of the donors; b. Plurality, because there are different actors; c. Decentralization, because despite the role of the OECD Development Assistance Committee, there is no central or hierarchically superior authority; d. Adaptation to the historical context, since it must be understood according to the moment, which reaffirms the above.

Those characteristics allow the inference that the typology of cooperation can be very varied. The same authors establish three categories for cooperation: a. According to its thematic scope (political, economic, technical and development promotion); b. According to their degree of institutionalization (informal or organic); c. By the number of participants (bilateral, multilateral and triangular) (Fernández Franco \& Román Marugán, 20I3). In order to escape the scope of this material, there is no need to deepen the different existing classifications and the one that considers the nature of donors and recipients is directly addressed, depending on whether these countries are from the north or south. According to this criterion, cooperation can respond to the North-South logic, when the donor is a developed country 
and the recipient is a developing country; and South-South ${ }^{56}$ when both donors and recipients are developing countries.

SSC is therefore the result of the search for a greater presence of emerging countries, which, lacking sufficient resources of hard power, use cooperation to reinforce their presence and influence in the area of interest (Velázquez Flores, Prado Lallande \& Díaz 20I5). Likewise, Hirst (20I2, I7) argues that SSC has an instrumental sense for foreign policy, which allows it to be valued as a soft power tool.

Although the literature, mainly in English, considers that the fields of study are: a. Financial funds for development (concessional loans with or without subsidized elements and non-concessional loans at commercial interest rate); b. Capacity building (technical cooperation, scholarships, exchange of experts, etc.); c. Funds for trade and investment facilitation (export credits, etc.), these are not the only ones. For its part, the studies about SSC have considered both, reimbursable and non-reimbursable funds. (Malacalza 2019, 73).

This reflects a political-technical dimension of SSC, which relates to instruments such as development finance and reimbursable funds in more favorable terms, among others. Malacalza (2019), presents an interesting summary of works that demonstrate this vision. The same author maintains that in addition to this dimension there is another: the economic-commercial one, which includes instruments such as non-refundable funds, on the related quality, there is a "curious shortage of work" (Malacalza 2019, 72).

\section{Taiwan as a player of international cooperation}

Firstly, the reasons why Taiwan provides international cooperation will be addressed. Following Chan (I997), there are two types of justifications, one legal and the other social. The first is established in the Taiwanese

5 Cohn (20I2) pointed out that the countries of the South are those least developed socially and economically speaking. They generally have a colonial past, their income levels per capita are more modest, the infrastructure for communications and transportation is inadequate and access to technological resources is limited. They may present institutional short comings and its relevance in the international system and international organizations is less significant.

6 Alemany, C., \& Freres, C. (2018, p. 63) state that the South is considered as a group of subordinate countries in the global system, which were not mostly distinguished, because "they were not relevant", since developed countries are the ones which determine the facts. The same authors argue that although emerging countries have gained relevance, they are still considered as an "undifferentiable set", with the exception of the so-called BRICS or other very particular sets. 
National Constitution (I947) 7 , which indicates in Article $\mathrm{I}_{4} \mathrm{I}^{8}$, its interest in fostering international cooperation. The second justification comes from an amalgam of political, economic, humanitarian and even moral factors. Taiwan recognizes these factors, as the island had previously received help to improve their well-being, they should now be prepared to provided assistance to less favoured countries ${ }^{\text {. }}$

Secondly, Annette Lu, who was Vice President of Taiwan between 2000 and 2008, emphasized the notion of soft power and applied it to the case of this island. Lu recognized five elements: a. Human rights; b. Democracy; c. Peace; d. Love; and e. High technology. Among them, the first one stands as the most important. Besides, Lee (2005) added three elements to those five: I. The will of the Taiwanese people to defend their country; 2. A civil defence mechanism; and 3. A close alliance with the United States and Japan. Those elements can also be considered as reasons for the international cooperation of this island.

The trajectory of Taiwan as donor started in I959 when it sent the first agricultural mission to Vietnam (Lemus Delgado 20I7). Even though, at that time, the country was still a developing one and a recipient of cooperation from the United States and various cooperation agencies such as the World Bank and the Asian Development Bank, among others (Chan I997). So, this was Taiwan's first effort on SSC, that had been lasting since then.

During the I96os, Taiwan undertook various initiatives within the framework of the China-Africa Technical Cooperation Committee, which implements agricultural projects with this continent. In I972, this institution was merged with the International Technical Cooperation Committee, which led the country's technical cooperation until i988. Then the International Economic Cooperation Development Fund (IECDF) was established. The latter was dissolved in I996 and the International Cooperation and Development Fund (ICDF) was installed (Lemus Delgado 20I7).

This evolution was influenced by external and internal factors. At the international level, recognition by other states and geopolitics is decisive for Taiwan's circumstances. These aspects are closely linked to that of cooperation in the Taiwanese case and are described below.

When the People's Republic of China was founded (October I ${ }^{\text {st }}$. I949), Beijing and Taipei began a struggle for international recognition (Rodríguez,

7 The constitution was amended in 2005

8 Chapter II: Fundamental National Policies, Section 2: Foreign Policy

9 Chan (I997) adopted this expression from an IECDF newsletter, where the Director of the Department of Operations, Neville H. Huang, gives the reasons why Taiwan cooperates. 
2008). Until I97I, Taiwan held China's representation at the United Nations. Then, the UN General Assembly adopted Resolution 2758 (XXVI) by which representatives of the People's Republic of China were recognized for their legitimacy in the organization and its quality of permanent member of the Security Council. Therefore, Taiwan's representatives were expelled.

Rodriguez (2008) explains that Taipei's dominance in the issue was reversed as an effect of some factors: the UN's decision, the decolonization process and the link between the Nixon Administration and Beijing. As proof of this, Taiwan's diplomatic recognition decreased rapidly. Only in Latin America and the Caribbean, Chile, Peru, Ecuador, Mexico, Argentina, Guyana, Jamaica, Trinidad and Tobago, Venezuela, Brazil, Suriname, Barbados and Colombia had established diplomatic relations with the People's Republic of China, between I970 and I980.

A significant year in the recent history of Taiwan was I979. At that moment, the United States, its main international supporter, changed its position on the island. In addition to this fact, Beijing opened a reform process. Furthermore, the Chinese Communist Party adopted modernization under socialism instead of the class struggle as its national priority (Wong 2000).

This situation, coupled with internal factors, such as the growing demand for citizen participation made Taipei modify its policies. Wong (2000) points out that when Chiang Ching-kuo died, it switched to a "Pragmatic Diplomacy" instead of the "Practical Diplomacy" that had been adopted until then. This change implied: the coexistence with the People's Republic of China was less tense, less rigidity around denominations and symbols and the improvement of relations with communist states. The subsequent end of the Cold War also had its repercussions for Taipei nationally and internationally.

In I987 Martial $\mathrm{Law}^{\mathrm{Io}}$ was repealed. This fact initiated a series of reforms that also had an impact on the relationship with China (Cornejo 2008). It is important to note that during the next years, Taiwan was developing its democracy, but with the positioning of the People's Republic of China, the recognition of several of its allies turned to Beijing.

That is the reason why cooperation with allied with Taiwan and which backed its international position had been very important, since it helped to sustain its claims in the current scenario. At the same time, this policy has been subject to the actions and instruments deployed by China in this dispute, among which cooperation is one of the key elements (Lemus Delgado 20I7).

Io It prohibited the formation of political parties, and also limited the possibility of gatherings and freedom of expression (Herrera Feligreras \& Lu 2006). 
After this brief review, some of the main features of the cooperation granted by Taiwan will be mentioned. Chan (I997) asserts that the Ministry of Foreign Affairs recommended to the ICDF that three conditions should be observed in order to be able to be eligible for cooperation with Taipei: a. Be a friendly country with Taipei; b. Have a good payment record; c. Gross National Product per capita less than USD 2,500.

The first of the conditions cited was very comprehensive. The meeting of the countries with which Taiwan maintained diplomatic relations and those with which it did not have this type of relationship, but which allowed the offices to operate under the name "Republic of China". Likewise, those with whom robust commercial or cultural ties are maintained; those who intended to improve their relations with Taipei and those who were not hostile. As noted, the criterion was broad and each case was addressed in a specific way by the respective authorities. As an example, we can cite the case of countries that were part of the Soviet orbit, which were negative at first and then "friendly" (Chan I997). The promotion of friendly relations with diplomatic allies is explicitly mentioned as one of the first goals in the provision of aid in the White Paper of the Taiwan Cooperation Policy (2009).

In addition to this last reason cited, this document points out as additional reasons: the fulfilment of Taiwan's responsibility as a member of the international community ${ }^{\mathrm{II}}$; the protection of human security; the retribution to the international community; and the development of the humanitarian sense.

The first region prioritized to receive cooperation was Asia as an area in which Taiwan belongs and with which it maintains strong commercial and investment ties. Secondly, Latin America and the Caribbean, as the region where the greatest number of allies was located, followed by Eastern Europe and Africa (Chan I997).

In general, Taiwanese development cooperation is divided into bilateral and multilateral. In the case of the first one, the following types of projects will be carried out: assistance with basic infrastructure, technical assistance, humanitarian assistance and those related to education and training. Meanwhile, multilateral initiatives are divided as such: donation to international organizations, contributions to funds for international cooperation, investments and financing through international organizations (Ministry of Foreign Affairs of Taiwan 2009).

II Chan (I997) pointed out that the Taiwanese experience in cooperation, considering the first it was both recipient and donor, allowed the country to transfer the knowledge of this process to other developing nations. This process was called the "Taiwan experience" by Taiwanese workers. 
In 1997 , the Taiwanese government consolidated its diverse cooperation projects in 1997 into a fund called the Taiwan International Cooperation and Development Fund (ICDF n. $\mathrm{d}^{\mathrm{I}}$ ), as previously mentioned. This institution sought, in accordance with Art. 7 of its founding letter, aspects such as: the promotion of social and economic development of recipient countries; cooperation with international organizations, institutions or governments that promote the promotion of social and economic development of recipient countries; the provision of humanitarian assistance to refugees or countries affected by natural disasters; technical assistance or services to strengthen industrial capacity; the completion of missions that improve and develop the agricultural, industrial, economic, medical and educational sectors of the recipient countries; and others that strengthen international cooperation and development with other countries.

The ICDF has a presence in the Latin American countries that it supports. This institution cooperates through technical and medical missions, humanitarian assistance projects, loans and investments and volunteers (Table I). According to the data published by the ICDF on its website (20I9), it has five technical missions in Central America and two in South America. Those mission are located at: Honduras, Nicaragua, Guatemala, Belize, one corresponding to Central America, Ecuador and Paraguay.

Table 1: Areas of cooperation of the ICDF in Latin America

\begin{tabular}{|l|l|l|l|l|l|}
\hline Country & $\begin{array}{c}\text { Missions } \\
\text { abroad and } \\
\text { medical } \\
\text { missions }\end{array}$ & $\begin{array}{c}\text { Technical and } \\
\text { humanitarian } \\
\text { assistance } \\
\text { projects }\end{array}$ & $\begin{array}{c}\text { Lending } \\
\text { and } \\
\text { investment } \\
\text { projects }\end{array}$ & $\begin{array}{l}\text { Volunteer } \\
\text { Program }\end{array}$ & $\begin{array}{c}\text { Youth } \\
\text { service } \\
\text { abroad }\end{array}$ \\
\hline Guatemala & Yes & Yes & Yes & No & Yes \\
\hline Ecuador & Yes & Yes & No & No & Yes \\
\hline El Salvador* & Yes & Yes & Yes & No & Yes \\
\hline Belize & Yes & Yes & Yes & Yes & Yes \\
\hline Honduras & Yes & Yes & Yes & No & Yes \\
\hline Nicaragua & Yes & Yes & Yes & Yes & Yes \\
\hline Panama* & No & Yes & No & Yes & No \\
\hline Paraguay & Yes & No & Yes & Yes & Yes \\
\hline
\end{tabular}

- El Salvador and Panama stopped recognizing Taiwan's sovereignty in August 20I8 and July 2017 respectively (Ríos, 20I9)

\section{Source: Lamus (2017)}

I2 Also known as the acronym FDICT. 


\section{The Bilateral relationship between Paraguay-Taiwan}

The emergence of this bilateral relationship must be understood in the context in which it had emerged. In I954 Alfredo Stroessner, a military officer who established a regime that ruled Paraguay until ig89 (Monte de López Moreira 20I2) came to power. Regarding foreign policy, Stroessner was practically the only gravitational actor in the decision-making process of Paraguay. The country opted for an international alignment with the United States (Salum-Flecha 20I2). This alignment developed into "a kind of marriage of convenience of the Cold War" (Scavone Yegros \& Brezzo, 20IO, I50). Mora and Cooney (2009) explained that this relationship with the United States resulted in a strong anti-communistic regime, which followed Washington's guidelines in exchange for legitimation and help.

In addition to this alignment with Washington, there was a change in the pendular policy that characterized Paraguay (Tini 2003). This fact caused the country to shift the focus from Argentina to Brazil, in a new strategy which was called "The March to the East" (Scavone Yegros and Brezzo 20I0). Moreover, relations with other political regimes such as the Apartheid in South Africa and Chiang Kai-shek in Taiwan were articulated. These links were marked by coincidences at the ideological level and the need to overcome international isolation (Nickson 20I4).

The relationship with Taiwan lasted over time despite the fact that in I97I the General Assembly of the United Nations resolved to restore to the People's Republic of China all of its rights in the organization and expel the representatives of Chiang Kai-shek through the Resolution 2758 (XXVI). This caused the process of Taiwan receding in the international system, due to the successive loss of recognition by other states.

Despite this, in 1979 the United States, Taipei's main international supporter, changed its guidelines and recognized Beijing (Wong 2000), Paraguay continued its relationship with Taiwan. The strength of these links can be seen through the number of bilateral agreements signed by both countries. From I957 to 20I8, 75 documents were signed, which ranged from diplomatic to cultural aspects, through commercial and economic cooperation treaties (Embassy of the Republic of Paraguay in the Republic of China (Taiwan) 2018). Table 2 provides a list of the agreements related to cooperation signed by Paraguay and Taiwan in the period I957 - 2007. 
Table 2: Agreements concerning cooperation signed between Paraguay and Taiwan (1957/2007)

\begin{tabular}{|c|c|c|c|c|}
\hline & Name of the instrument & $\begin{array}{l}\text { Signature } \\
\text { date }\end{array}$ & $\begin{array}{l}\text { Ratification } \\
\text { in Paraguay }{ }^{13}\end{array}$ & $\begin{array}{l}\text { Entry into } \\
\text { force }\end{array}$ \\
\hline I & Trade and Economic Cooperation Treaty ${ }^{\mathrm{I}}$ & II/05/I962 & $\begin{array}{c}\text { Law 8II } \\
(\mathrm{I} 8 / 07 / \mathrm{I9} 62) \\
\end{array}$ & 29/12/1962 \\
\hline 2 & $\begin{array}{l}\text { Act on Technical and Economic } \\
\text { Cooperation }\end{array}$ & 26/08/1971 & --- & --- \\
\hline 3 & $\begin{array}{l}\text { Agreement by Diplomatic Notes } \\
\text { regarding the formation of the Chinese } \\
\text { Agricultural Technical Mission in } \\
\left.\text { Paraguay (N.R. } \mathrm{N}^{\circ} \mathrm{I} / 73 .\right)^{\mathrm{I5}}\end{array}$ & I5/02/I973 & --- & I5/02/1973 \\
\hline 4 & $\begin{array}{l}\text { Educational Cooperation Agreement in } \\
\text { the Scientific and Technological Field }{ }^{16}\end{array}$ & I9/06/1990 & $\begin{array}{c}\text { Law II3 } \\
\text { (03/0I/I99I) }\end{array}$ & I9/06/1990 \\
\hline 5 & $\begin{array}{l}\text { Agreement by Diplomatic Notes } \\
\text { concerning the Donation of USD } 20 \\
\text { million for the construction of a new } \\
\text { headquarters for the National Congress. } \\
\text { (N.R. No. I8/94) }\end{array}$ & 2I/I2/I994 & $\begin{array}{c}\text { Law } 560 \\
28 / 04 / 1995)\end{array}$ & 03/05/1995 \\
\hline 6 & $\begin{array}{l}\text { Letter of Intent on cooperation in the } \\
\text { planning study of a new city of Asunción }\end{array}$ & $26 / 08 / 1995$ & --- & 05/10/1998 \\
\hline 7 & $\begin{array}{l}\text { Memorandum of Understanding for } \\
\text { the promotion of an industrial park in } \\
\text { Paraguay }\end{array}$ & 26/08/1995 & --- & 26/08/1995 \\
\hline 8 & $\begin{array}{l}\text { Agreement by Diplomatic Notes } \\
\text { regarding the Cyber Modernization Plan } \\
\text { of the Ministry of Foreign Affairs (N.R. } \\
\text { No. } 5 / 96 . \text { ) }\end{array}$ & I4/08/1996 & --- & I4/08/I996 \\
\hline 9 & $\begin{array}{l}\text { Agreement by Diplomatic Notes for the } \\
\text { construction of a bridge between the city } \\
\text { of Asunción and the Western Region } \\
\text { (N.R. No. 9/97.) }\end{array}$ & I7/09/I997 & --- & I7/09/I997 \\
\hline IO & $\begin{array}{l}\text { Memorandum of Understanding on } \\
\text { financial cooperation to the agricultural } \\
\text { sector }\end{array}$ & I7/09/I997 & --- & I7/09/I997 \\
\hline II & $\begin{array}{l}\text { Agreement by Diplomatic Notes on } \\
\text { the promotion of trade and training of } \\
\text { human resources }\end{array}$ & I7/09/I997 & -- & I7/09/I997 \\
\hline $\mathrm{I} 2$ & $\begin{array}{l}\text { Agreement by Diplomatic Notes on Non- } \\
\text { Refundable Economic Cooperation for } \\
\text { the implementation of the metropolitan } \\
\text { network in the Ministry of Foreign } \\
\text { Affairs. N.R. No IO/97 }\end{array}$ & 10/10/I997 & --- & Io/I0/I997 \\
\hline
\end{tabular}




\begin{tabular}{|c|c|c|c|c|}
\hline I3 & $\begin{array}{l}\text { Memorandum of Understanding on } \\
\text { Economic Cooperation Programs }\end{array}$ & I7/08/I998 & --- & I7/08/I998 \\
\hline I4 & $\begin{array}{l}\text { Agreement by Diplomatic Notes of } \\
\text { Economic Cooperation Non-refundable } \\
\text { to be destined to the Export Project of } \\
\text { horticultural items, fruits, flowers and to } \\
\text { a lesser degree cattle }\end{array}$ & 05/10/1998 & --- & 05/10/1998 \\
\hline I5 & $\begin{array}{l}\text { Memorandum of Understanding on the } \\
\text { Action Plan }\end{array}$ & 16/09/1999 & -- & I6/09/1999 \\
\hline I6 & Agreement on sending volunteers & $20 / 12 / 2005$ & --- & $27 / \mathrm{II} / 2007$ \\
\hline
\end{tabular}

Source: Compilation based on information supplied by Embassy of Paraguay in Taipei (2017)

\section{Cooperation projects during the 2009-2019 period}

Taiwan's cooperation with Paraguay is long-standing and has various facets as previously noted. In this section, three aspects will be considered: the bilateral cooperation agreements signed; the projects undertaken by the ICDF; and other initiatives.

\section{Bilateral Cooperation Agreements}

I. During the 2009 - 2019 period, eight documents related to cooperation were signed. They are cited below:

2. Act of Receipt of Disbursement of USD 7I Million from the Republic of China (Taiwan) to the Republic of Paraguay (2009) Sports (2009)

3. Agreement for Cooperation in Culture, Education, Science and

4. Agreement by Diplomatic Notes on the Modification of the Agreement by Diplomatic Notes of 02/15/1973 regarding the formation of the Chinese Agricultural Technical Mission in Paraguay (20I0)

I3 The ratification of the instruments is carried out according to the nature of the instrument and its content. For this reason, there are in the previous table, instruments that required this procedure and others that did not.

I4 It was extended in I972 for Io more years and in I995 an Update Protocol was signed.

I5 In I995, a Memorandum of Understanding on the strengthening of the TechnicalAgricultural Cooperation Plan was signed.

I6 Extended in I995, during an official visit of Paraguay's President Juan Carlos Wasmosy 
5. Act of Disbursement of USD 737,000 granted by the Republic of China (Taiwan) to the Republic of Paraguay for the financing of the priority project of the Ministry of Foreign Affairs (2010)

6. Act of Disbursement of USD 500,000 granted by the Republic of China (Taiwan) to the Republic of Paraguay for the project of the modernization and strengthening of institutional management of the Ministry of Foreign Affairs (20I3)

7 Memorandum of Understanding on non-refundable financial cooperation period 20I3-20I8 (20I4)

8. Economic Cooperation Agreement (20I7)

9. Memorandum of Understanding on non-refundable financial cooperation period 2018-2023 (2018)

The first of the documents signed was the Act of Disbursement of donation of US \$ 7I million from the Republic of China (Taiwan) to the Republic of Paraguay, which dates from July 9, 2009. The goal of the aforementioned sum of money was the strengthening of the linkage and bilateral cooperation between both countries and it would be destined to the priority programs of the Paraguayan government (Government of the Republic of Paraguay \& Government of the Republic of China (Taiwan) 2009).

Within the framework of this donation, an advance of US\$24 million was delivered in 2008. This amount was used for the regularization of settlements, agricultural policies, sustainable settlements, administration of public works and housing solutions. With the signing of the Act, another US\$ 8 million was delivered, while before August 20 Io US\$ 8,888,400 was transferred and the balance of US\$30,III,600 was made available before August 2013 (Ministry of Finance 2009).

The funds received, according to Decree No. 2775/2009, were allocated to the programs and projects previously mentioned and other various institutions. Some of them are mentioned below: the Ministry of Interior, the Ministry of Education and Culture, the Ministry of Industry and Commerce, the Ministry of Foreign Affairs ${ }^{17}$ and the Ministry of Defence, among other State agencies.

The second of the instruments cited was the Agreement for

I7 The record of donors received by the Ministry of Foreign Relations are reviewed in the seven mentioned signed instruments, and also are a part of the distributions of donation of US\$ 7I millions that were made in the 2008-20I3 period. The expenditure of US\$737.000 was destined to the "Project of Improvement of Technology and Communications" and of US\$ 500.000 to a project to improve the institutional management of the organization. 
Cooperation in Culture, Education, Science and Sports. It was signed on September 8, 2009 and was intended to promote cooperation in the detailed areas. Various actions would be carried out for this aim, for example: visits from personalities, exchange of institutions, granting of scholarships, to the promotion of cultural industries, to name just a few.

This agreement served as a framework for the creation of the TaiwanParaguay Polytechnic University, which was established as a public institution in 20I8. The majority of teachers are part of the staff of the National Taiwan University of Science and Technology. It should be noted that in the first half of 2019 it admitted Iog students in their four careers: Civil Engineering, Electromechanical Engineering, Industrial Engineering and Computer Engineering.

On April 8, 2010, an agreement was signed by Diplomatic Notes for the modification of the conformation of the Chinese Agricultural Technical Mission in Paraguay. The first of the points outlined was the interpretation of the technical mission as part of the technical cooperation between the parties and its execution in accordance with the Agreement of 1973. It was also established that the mission projects should relate to the following topics:

a) Horticulture and fruit growing, livestock, processing of agricultural products, as well as promotion and administration of agricultural industries

b) Aquaculture

c) Public health and medical cooperation

d) Cooperation and promotion of the economy and commerce (Industrial Park)

e) Cooperation in the areas of information, communication or technology

Two other points indicated were the places of implementation of the projects, which should be agreed to by both governments, and the use of resources in the initiatives carried out.

The documents previously cited in this section were signed during the Fernando Lugo government ${ }^{18}$. With the arrival of Horacio Cartes (2013 20I8) to power, new donations were made by the Taiwanese government, as well as in the beginning of the period of Mario Abdo Benítez (20I8 -). This is a recurring practice overtime: the delivery of a donation from Taiwan to be

I8 The Lugo government was in power since $15 / 08 / 2018$ and was overthrown by a judicial measure in 22/06/2012. He was succeeded by his Vice-President Federico Franco, that delivered the power to Horacio Cartes. 
distributed, by the incoming government to the institutions or projects which it considers as its priority.

The Memorandum of Understanding on Non-Refundable Financial Cooperation 2013-20I8 was signed in 20I4. The same, a difference of the diversity of initiatives considered in the previous period, that the total sum: US\$ 7I million, would be completely destined to the project "Che Tapyi Housing solutions". Their objectives are "To improve the living conditions of the inhabitants with the provision of housing, health posts, community centers, energy and drinking water services and reducing the lack of housing for the population that is in a situation of poverty and extreme poverty" (Ministry of Urban Planning, Housing and Habitat of Paraguay n.d.)

Other actions were in 20I7 a new Economic Cooperation Agreement was signed between Paraguay and Taiwan. This instrument aimed to strengthen the economic, commercial relationship and liberalize trade and investment. It should be noted that it also considers diverse elements: Small and Medium Enterprises, technical barriers to trade and intellectual property and others.

Last but not least, it is important to mention that in 2018 the Memorandum of understanding on non-refundable financial cooperation 2018-2023 was signed. This document was ratified by Law No. 6275/2018. It contemplates, in accordance with the new bilateral agenda, projects in the following areas: social and humanitarian assistance, education, housing solutions, road infrastructure, security and defences, public health.

\section{Projects undertaken by the ICDF}

Taiwanese cooperation implemented, through the ICDF, resulted in I6 projects between 2010 and 2019 (Table 3). The majority is concentrated on technical cooperation projects, representing $43.75 \%$ of the actions undertaken, and humanitarian assistance $37.5 \%$. The other areas of the ICDF action: education and international training and loans and investments, are not so relevant according to the observed data.

On Table 3, interesting features can be seen in the type of projects financed. The first one is linked to the issues addressed in the cooperation projects. It can be observed that there are three projects related to aquaculture and the same number related to floriculture, as well as three initiatives related to the topic of training of health professionals or health management.

Another significant feature refers to the time span of the projects. Considering the majority of projects, already completed as of August 20I9, 
the duration of the projects was, on average, 32.78 months. It should be noted that the actions of the area of humanitarian assistance for the same period, showed an average of I5.25 months, well below that observed for all technical cooperation projects, which had an average duration of 46.8 months.

Table 3: ICDF cooperation projects in Paraguay (2009 - 2019)

\begin{tabular}{|c|c|c|c|c|}
\hline & Name of the Project & Area & Beginning Date & $\begin{array}{c}\text { Date of } \\
\text { finalization }\end{array}$ \\
\hline I & Floriculture Project & $\begin{array}{l}\text { Technical } \\
\text { cooperation }\end{array}$ & OI/OI/20IO & $\mathrm{I} 2 / 3 \mathrm{I} / 2 \mathrm{OI} 3$ \\
\hline 2 & Aquaculture Project & $\begin{array}{l}\text { Technical } \\
\text { cooperation }\end{array}$ & OI/OI/2OIO & $\mathrm{I} 2 / 3 \mathrm{I} / 2 \mathrm{OI} 3$ \\
\hline 3 & Mobile medical mission & $\begin{array}{l}\text { Humanitarian } \\
\text { assistance }\end{array}$ & OI/OI/2OII & $\mathrm{I} 2 / 3 \mathrm{I} / 2 \mathrm{OII}$ \\
\hline 4 & $\begin{array}{l}\text { Healthcare Personnel Training } \\
\text { Program }\end{array}$ & $\begin{array}{c}\text { Humanitarian } \\
\text { assistance }\end{array}$ & OI/OI/2OI2 & $\mathrm{I} 2 / 3 \mathrm{I} / 2 \mathrm{OI} 4$ \\
\hline 5 & $\begin{array}{l}\text { Assistance to rural populations } \\
\text { affected by the food emergency } \\
\text { due to the effects of drought }\end{array}$ & $\begin{array}{l}\text { Humanitarian } \\
\text { assistance }\end{array}$ & $\mathrm{II} / \mathrm{I} 5 / 20 \mathrm{I} 2$ & I2/I5/20I2 \\
\hline 6 & Feed Production Project & $\begin{array}{c}\text { Technical } \\
\text { cooperation }\end{array}$ & 04/OI/20I3 & $\mathrm{I} 2 / 3 \mathrm{I} / 20 \mathrm{I} 7$ \\
\hline 7 & $\begin{array}{c}\text { Pacu Fingerling Breeding and } \\
\text { Cultivation Project }\end{array}$ & $\begin{array}{c}\text { Technical } \\
\text { cooperation }\end{array}$ & $\mathrm{II} / 24 / 20 \mathrm{I} 4$ & II $/ 23 / 20 I 7$ \\
\hline 8 & $\begin{array}{c}\text { Healthcare Personnel Training } \\
\text { Program }\end{array}$ & $\begin{array}{l}\text { Humanitarian } \\
\text { assistance }\end{array}$ & OI/OI/2OI5 & $\mathrm{I} 2 / 3 \mathrm{I} / 20 \mathrm{I} 5$ \\
\hline 9 & $\begin{array}{l}\text { Orchid Industry Development } \\
\text { and Tissue Culture Plantlet } \\
\text { Propagation Project (Paraguay) }\end{array}$ & $\begin{array}{c}\text { Technical } \\
\text { cooperation }\end{array}$ & $02 / 10 / 2015$ & $\mathrm{II} / 23 / 20 \mathrm{I} 8$ \\
\hline IO & $\begin{array}{c}\text { Health Information } \\
\text { Management Efficiency } \\
\text { Enhancement Project in } \\
\text { Paraguay }\end{array}$ & $\begin{array}{l}\text { Humanitarian } \\
\text { assistance }\end{array}$ & OI/OI/20I6 & I2/3I/20I9 \\
\hline II & $\begin{array}{l}\text { Surubi Fingerling Breeding } \\
\text { and Cultivation Project }\end{array}$ & $\begin{array}{c}\text { Technical } \\
\text { cooperation }\end{array}$ & $\mathrm{I} 2 / 0 \mathrm{I} / 20 \mathrm{I} 8$ & $\mathrm{I} 2 / 3 \mathrm{I} / 2022$ \\
\hline I2 & $\begin{array}{l}\text { TaiwanICDF Overseas } \\
\text { Volunteers Program }\end{array}$ & $\begin{array}{l}\text { Humanitarian } \\
\text { assistance }\end{array}$ & OI/OI/20I9 & I2/3I/20I9 \\
\hline I3 & Taiwan Youth Overseas Service & $\begin{array}{c}\text { Technical } \\
\text { cooperation }\end{array}$ & OI/OI/20I9 & I2/3I/20I9 \\
\hline I4 & $\begin{array}{l}\text { Project to Strengthen Capacity } \\
\text { to Support Development of } \\
\text { MSMEs }\end{array}$ & n.i. & OI/OI/2OI9 & $\mathrm{I} 2 / 3 \mathrm{I} / 2022$ \\
\hline
\end{tabular}




\begin{tabular}{|c|c|c|c|c|}
\hline I5 & $\begin{array}{c}\text { Project to Strengthen Capacity } \\
\text { for Commercial Production of } \\
\text { Orchids }\end{array}$ & $\begin{array}{c}\text { Technical } \\
\text { cooperation }\end{array}$ & 04/0I/20I9 & 03/3I/202I \\
\hline I6 & $\begin{array}{c}\text { Overseas Professional } \\
\text { Mandarin Teaching Project }\end{array}$ & $\begin{array}{c}\text { International } \\
\text { education and } \\
\text { training }\end{array}$ & n.d & n.d. \\
\hline
\end{tabular}

Source: ICDF (2019)

\section{Other initiatives}

Scholarships granted by the Taiwanese government are also an important element of the cooperation of this Asian country with Paraguay. According to Ferreira (20I7) between I99I and 20I7, 304 scholarships were granted to young Paraguayans and state officials to continue their studies in Taiwan in disciplines related to Engineering, Business Administration, Science, Electrical Engineering, Computer Science and Social Sciences.

Among them, there are several types. The first one is called "Taiwan Scholarships" and they were awarded to 234 people in the referred period. These grants comprise five years studies, including one year for language learning.

There are also four other types of scholarships. First, the ones defined as "Huayu Scholarships" through which it is possible to study ChineseMandarin for a period between 6 and 12 months. This kind of scholarship had 4I beneficiaries between I99I and 20I7. The second type is the called "Medical Scholarships" aimed at students in the health area. The third type is the "Executive Master's Scholarships online". Through those, I2 public servants have participated online studies in their native language. The last is "ICDF Scholarships" that allowed I5 people to study undergraduate, master's and doctoral studies in English (Ferreira, 20I7).

In addition to the initiatives mentioned above, there are other actions that seek to promote economic cooperation between the two countries. In these lines, only two of them will be mentioned: The Conferences on Economic Cooperation and the promotion for the participation of Paraguayan companies in trade fairs in Taiwan.

The Conferences on Economic Cooperation have been held since I987. This event, that happens from time to time without a definitive schedule, is alternatively held either in Taipei or in Asunción. Authorities of the highest level of both governments and businessmen of the countries, interested in searching for business opportunities were the participants. 
It is important to mention that from different official agencies of both countries, the participation of Paraguayan companies in trade fairs was supported, specifically in Food Taipei. This trade fair is one of the most known food exhibitions in Southeast Asia and Paraguayan companies participated in various editions of it.

Finally, and despite not being the focus of this material, it is important to note that there are also two loans from the Export-Import Bank of the Republic of China, which are being honored. The first one dates from 2013, amounts to US\$20 million and was destined to development projects in the agricultural sector. While the second, was represented by an amount of US\$ 70 million that was used for financing projects for agricultural cooperatives, development of small and medium enterprises and construction of roads.

\section{Some Final Thoughts}

Taiwan has a rich history that encompasses various stages in recent centuries. In the second half of the twentieth century, with the founding of the People's Republic of China, it had to put forward several efforts to promote its international recognition against the ones that the RPC gained.

One of the countries with which it was linked is Paraguay. Since 1957 it has maintained uninterrupted diplomatic relations. Although the relationship arose in the middle of the Cold War, it continued over time despite the evolution of the international system and the various diplomatic setbacks that this Asian territory had. Over the years this relationship has become even more relevant. Since October 2019, 15 countries have recognized Taiwan, of which this Latin American state is the only one in the Southern Cone. This situation promotes that the relationship and cooperation are intense.

South-South cooperation results from the need to increase the presence of emerging countries, which use it as a soft power tool in the face of their limited hard power. In addition, it is important to mention that this type of cooperation has two dimensions. Firstly, a political-technical dimension, in which development finance and reimbursable funds, are considered in more favourable terms. Secondly, an economic-commercial one, which includes, for example, non-reimbursable funds. The latest of which was considered for the cooperation of Taiwan to Paraguay in the 2009-2019 period. 
In the period considered in this research, eight instruments were signed. They served as a framework for different projects. One of the main features identified is the agreement signed at the beginning of each five-year period of the incoming government. This document details the amount to be donated and its purpose. The aims of the cooperation change according to the interests of the incoming authorities and the bilateral agenda. During the 2008 - 2013 and 2013 - 2018 periods, the amount donated was US\$ 71 million at each round. Meanwhile for 2018 - 2023 period the amount committed was US\$ 150 million.

It is possible to observe that the issue of housing solutions was common in the projects undertaken. However, Lugo and Abdo Benítez selected a list of other issues, while Cartes allocated the entire amount to the "Che Tapyi - Housing Solutions" project.

Regarding the work of the ICDF in Paraguay, this institution developed 16 projects between 2010 and 2019. And, as previously mentioned, the majority of the projects focused on technical cooperation projects and humanitarian assistance projects. The main issues addressed in cooperation projects are related to aquaculture, floriculture and the training of health professionals and health management, among others. Another kind of cooperation are the scholarships, the organization of Economic Cooperation Conferences and participation in trade fairs.

\section{REFERENCES}

Alemany, C., \& Freres, C. (20I8). América Latina en busca de una inserción efectiva en la agenda internacional de la cooperación para el desarrollo. Revista de Cooperación y Desarrollo, 5(I), 59-84.

Arnone, A. G. (20I7). A 105 años de la fundación del partido Kuomintang en China. http://www.iri.edu.ar/wp-content/uploads/20I7/o8/Arnone. pdf

Ayllón, B. (2007). La Cooperación Internacional para el Desarrollo: fundamentos y justificaciones en la perspectiva de la Teoría de las Relaciones Internacionales. Carta Internacional, 2(2), 7-22. I/2/20I5.

Bloom, W. (I990). Personal identity, national identity and international relations. Cambridge University Press.

Calabuig Tormo, C., Gómez-Torres, M. de los L., Boni Aristizábal, A., Cuesta 
Fernández, I., Lozano Aguilar, J. F., Monzó Balbuena, J. M., \& Torres Martínez, A. J. (2010). La Cooperación Internacional para el Desarrollo. Edición revisada. (Calabuig Tormo, Carola y Gómez-Torres María). Fustabloc. http://www.upv.es/upl/U0566378.pdf

Central Intelligence Agency. (20I9). Taiwan. The World Factbook. https:// www.cia.gov/library/publications/resources/the-world-factbook/ geos/tw.html

Chan, G. (1997). Taiwan as an Emerging Foreign Aid Donor: Developments, Problems, and Prospects. Pacific Affairs, 70(I), 37-56. JSTOR. https:// doi.org/10.2307/2761227

China Continental desembarca en Paraguay. (2018, August 23). Diario 5 dias. https://www.5dias.com.py/20I8/o8/china-continental-desembarcaen-paraguay/

Cohn, T. (20I2). Global Political Economy (6). Pearson Education Limited.

Cornejo, R. (2008). La participación política y los desafíos de las nuevas democracias: notas sobre China y Taiwán. In La globalización y el Consenso de Washington: sus influencias sobre la democracia y el desarrollo en el sur (pp. 215-235). http://biblioteca.clacso.edu.ar/clacso/sursur/20100711084629/12corne.pdf

Embajada de la República de China (Taiwán) en la República del Paraguay. (2019, July). Universidad Politécnica Taiwán-Paraguay (UPTP) convoca al Curso de Inducción 2019 para el Examen de Ingreso 2020. Embajada de La República de China (Taiwán) https://www.roc-taiwan.org/py_ es/post/13783.html

Embajada de la República del Paraguay en la República de China (Taiwán). (2018). Instrumentos Bilaterales suscritos entre la República del Paraguay y la República de China (Taiwán). https://www.embapartwroc.com. tw/convenios_bilaterales_es

Esteban, M. (2008). The diplomatic battle between Beijing and Taipei in Latin America and the Caribbean. Fifth Conference of the European Association of Taiwan Studies, Praga. https://www.soas.ac.uk/taiwanstudies/eats/ eats2008/file43i80.pdf

Fernández Franco, L., \& Román Marugán, P. (2013). Manual de cooperación al desarrollo. Síntesis Editorial.

Ferreira, N. (n.d.). En 26 años, Taiwán otorgó 304 becas de estudios a paraguayos. Diario La Nación. Retrieved 28 October 2019, from /20I7/02/05/26-anos-taiwan-otorgo-304-becas-estudios-paraguayos/

Fleitas, C. J. (20I7, April 29). Conferencia sobre los 60 años de Relaciones 
Diplomáticas entre Paraguay y la República de China (Taiwán). Conferencia sobre los 60 años de Relaciones Diplomáticas entre Paraguay y la República de China (Taiwán). http://www.stp.gov.py/vi/wpcontent/uploads/20I7/05/Presentaci_n_6o_a_os_de_relaciones_ diplom_ticas_Pa.pdf

General Assembly - United Nations Organization. Restitución de los legítimos derechos de la República Popular China en las Naciones Unidas, 2758 (XXVI) Resolución (1971). https://undocs.org/es/A/RES/2758(XXVI)

Taiwan (Republic of China)'s Constitution of I947 with Amendments through 2005, (2005). https://www.constituteproject.org/constitution/ Taiwan_2005.pdf?lang=en

Gobierno de la República de China (Taiwán), \& Gobierno de la República del Paraguay. (2009). Convenio para Cooperación en los Ámbitos de la Cultura, la Educación, las Ciencias y el Deporte.

Gobierno de la República de China (Taiwán), \& Gobierno de la República del Paraguay. (2010). Notas Reversales para la modificación de la conformación de la Misión Técnica Agrícola China en Paraguay.

Gobierno de la República de China (Taiwán), \& Gobierno de la República del Paraguay. (20I4). Memorando de Entendimiento sobre Cooperación Financiera No Reembolsable Periodo 2013-2018.

Gobierno de la República de China (Taiwán), \& Gobierno de la República del Paraguay. (20I7). Acuerdo de Cooperación Económica entre Paraguay Y Taiwán.

Gobierno de la República de China (Taiwán), \& Gobierno de la República del Paraguay. (20I8). Memorando de Entendimiento sobre Cooperación Financiera No Reembolsable Periodo 2018-2023.

Acta de recepción de desembolsos de la donación de dólares de los Estados Unidos de América setenta y un millones, de la República de China (Taiwán) a la República del Paraguay, (2009).

Herrera Feligreras, A., \& Lu, Y.-T. (2006). Taiwan, cambio político e identidad nacional. Huarte de San Juan. Geografía e Historia, I3, I3I-I5O.

Hirst, M. (20I2). Aspectos conceituais e práticos da atuação do Brasil em cooperação sul-sul: os casos de Haiti, Bolívia e Guiné Bissau. Instituto de Pesquisa Econômica Aplicada. http://www.ipea.gov.br/ portal/images/stories/PDFs/TDs/td_I687.pdf

ICDF. (20I9). Central America [HTML]. https://www.icdf.org.tw/ lp.asp? ctNode $=29868 \&$ CtUnit=I99\&BaseDSD=IOI\&mp $=2$

International Cooperation and Development Fund. (n.d.). About 
the Taiwan ICDF. https://www.taiwanembassy.org/public/ Attachment/oI202236347I.pdf

Lee, S. (2005). A New Interpretation of "Soft Power" for Taiwan. Taiwan International Studies Quarterly, 2(I), I-23.

Lemus Delgado, D. (20I7). La Ayuda Oficial al Desarrollo de Taiwán en América Latina a la sombra de China: Entre la identidad nacional y el reconocimiento internacional. Revista Internacional de Cooperación $Y$ Desarrollo, 4(2), 5I-67.

Library of the Congress of the United States of America. (2005). Country profile: Taiwan. https://www.loc.gov/rr/frd/cs/profiles/Taiwan.pdf

Malacalza, B. (20I9). La política de la cooperación Sur-Sur. China, India y Brasil en América Latina y el Caribe. Colombia Internacional, 98, 67-IO3.

Ministerio de Hacienda. (2009). Acta de recepción de desembolsos de la donación de dólares de los Estados Unidos de América setenta y un millones, de la República de China (Taiwán) a la República del Paraguay.

Ministerio de Hacienda. (20I9). Paraguay-Taiwan. http://www.economia. gov.py/index.php/dependencias/direccion-deintegracion/bilaterales / paraguay-estados-unidos-I

Ministerio de Urbanismo, Vivienda y Hábitat del Paraguay. (n.d.). Che Tapyi. Retrieved I8 October 2019, from https://www.muvh.gov. py/?programas $=$ che-tapyi

Ministry of Foreing Affairs - Republic of China (Taiwan). (2009). White Paper on Foreign Aid Policy. https://www.mofa.gov.tw/Upload/ RelFile/II20/588/cd6ed55I-6f33-478f-a96d-f6053bc2e959.pdf

Monte de López Moreira, M. (20I2). Historia del Paraguay. Servilibro.

Mora, F. O., \& Cooney, J. (2009). El Paraguay Y Estados Unidos. Intercontinental Editora.

Nickson, A. (20I4). La Guerra Fría y el Paraguay. El Lector.

Por el cual se modifica el anexo del decreto nffl iı822 del 6 de febrero de 2008 "Por el cual se acepta la donación otorgada por la República de China (Taiwán) a la República del Paraguay, destinada al financiamiento de proyectos prioritarios en el marco del acuerdo de cooperación bilateral suscrito entre ambos países", (2009).

Ríos, X. (2016). El Conflicto China-Japón. Observatorio Iberoamericano de La Economía y La Sociedad Del Japón, 25, II3-I28.

Ríos, X. (2019). El estado de las relaciones China - América Latina (I/2019). https://www.fundacioncarolina.es/wp-content/uploads/2019/03/ 


\section{DT_FC_oI.pdf}

Rodríguez, M. E. (2008). La batalla diplomática de Beijing y Taipéi en América Latina y el Caribe. Revista Cidob d'Afers Internacionals, 8I, 209-23I.

Salum-Flecha, A. (2012). Origen, Desarrollo y Modernización de la Política Exterior del Paraguay. Intercontinental Editora.

Scavone Yegros, R., \& Brezzo, L. (2010). Los tiempos de Stroessner y la transición a la democracia. In Historia de las Relaciones Internacionales del Paraguay (Vol. I9). El Lector.

Silva Vera, C. P., \& Cruz Aguilar, B. A. (2015). La política externa paraguaya: un estudio comparativo entre los gobiernos de Fernando Lugo (2008-20I2) y Horacio Cartes (20I3-20I4). I Encontro Internacional de Política Externa Latinoa-Americana: Mapeando a Política Externa do Cone Sul, Foz do Yguaçu. https://dspace.unila.edu. br/bitstream/handle/I23456789/I513/NUPELA\%20-\%207-I7. pdf? sequence $=\mathrm{I} \&$ isAllowed $=\mathrm{y}$

Sotillo, J. A. (20II). El sistema de cooperación para el desarrollo. Actores, formas y procesos. Los libros de la Catarata.

TaiwanICDF Introduction. (n.d.). Retrieved 6 August 2019, from http:// www.icdf.org.tw/ct.asp? xItem $=4470 \& C t N o d e=29840 \& \mathrm{mp}=2$

Tini, M. N. (2003). Argentina - Paraguay, una relación especial. Relaciones Internacionales, 25, I-29.

Toro Dávila, A., Chacón Morales, A., \& Pérez Le-Fort, M. (200I). La República Popular China y el conflicto con Taiwán: un estrecho margen de maniobra. Estudios Internacionales, 34(I33), 7I-IO7.

Velázquez Flores, R., Prado Lallande, P., \& Díaz, I. (2015). Relaciones Internacionales y desarrollo global: enfoques teóricos y mecanismos de promoción. In Los estudios del desarrollo global en perspectiva (pp. 79-105). Universidad de Baja California. https://www.academia. edu/39I20I7I/Relaciones_Internacionales_y_desarrollo_global_ enfoques_te\%C3\%B3ricos_y_mecanismos_de_promoci\%C3\%B3n

Wong, T. K. (2000). Changing Taiwan's foreign policy: from one China to two states. Asian Perspective, 24(I), 5-46. JSTOR. 


\section{ABSTRACT}

Taiwan's situation in the international system is particular and the recognition of other states is key to its survival. Since I957, Paraguay has maintained diplomatic relations with this Asian country. This research aims to describe the South - South cooperation of Taiwan with Paraguay during the $2009-2019$ period, a very important characteristic of the bilateral relationship between both parties. In order to do this, we base the article on a descriptive bibliographic documentary research, considering primary and secondary sources regarding the focus of the study. Among the main results obtained, it can be seen that non-reimbursable cooperation projects are being adjusted according to five-year negotiations, that there is some continuity regarding the issues addressed by technical cooperation and the existence of other less known initiatives such as conferences and participation in fairs.

\section{KEYWORDS}

South-South Cooperation; Republic of China (Taiwan); Paraguay.

Received on February 24, 2020

Approved on May 8, 2020 